Stephen Leon J

Department of Mechanical Engineering Saveetha School of Engineering Saveetha Institute of Medical and Technical Sciences, Chennai, Tamilnadu

Bharathiraja G

Department of Mechanical Engineering Saveetha School of Engineering Saveetha Institute of Medical and Technica Sciences, Chennai, Tamilnadu

India

Jayakumar V

Department of Mechanical Engineering Amrita School of Engineering,Chennal Amrita Vishwa Vidyapeetham

India

\section{Experimental Analysis on Friction Stir Welding using Flat-Faced Pins in AA2024-T3 Plate}

In friction stir welding, lesser tool life restricts the usage of non-circular pin in friction stir welding tool eventhough it delivers comparatively better weld joints than circular pin. Process peak temperature during the process affects the shear strength of the flowing material around the tool pin. Maintaining the process peak temperature as low as possible improves the properties in heat affected zone but on the other hand it increases the stress on the tool pin.Especially on the usage of non-circular pin, the pin surface experiences uneven stress distribution and causes premature tool failure. In this paper, optimum thermal environment through proper selection of process parameters and dwell period with respect to the pin geometry are analysed. A comparative analysis is also made to understand the impact of increase in flat surfaces in the pin surface on weld quality in the view of developing a suitable thermal environment that can improve tool life without compromising joint strength. Apart from this, optimum dwell period for the chosen tool pin geometry is analysed based on the empirical softening temperature of the material.

Keywords: Friction stir welding, experimental analysis, non-circular tool pin, dwell period, mechanical property, thermal analysis.

\section{INTRODUCTION}

Friction stir welding, being a completely solid state joining process, eliminates major problems associated with other molten state joining processes. Especially this solid state joining process is much suitable to join aluminium plates because of its easily oxidising nature when it contacts atmospheric air in its molten state. This joining process is divided into several stages based on the position of the tool as shown in Fig.1. Rotary and sliding motion of the tool on the surface of the stationary base metal along the joining line generates frictional heat. This frictional heat input increases the temperature of the material to be joined. As the yield strength of the material is inversely proportional to the temperature rise, an increase in temperature reduces the strength of the material. Process temperature during the joining process increases till the material becomes soft enough to transfer the torque generated by the tool to the material under the tool shoulder. The transfer of torque from tool to base metal induces severe plastic strain on material along the weld line which results in joining of workpieces[1].

Although plastic deformation of the material generates some quantity of heat, the entire joining process depends on heat generated through the friction along the tool/matrix interface[2]. The success of this joining process completely depends on the tool/matrix contact heat input boundary conditions. Contact surface

Received: July 2020, Accepted: October 2020

Correspondence to: Stephen leon J

Saveetha Institute of Medical and Technical Sciences,

Chennai, Tamilnadu, India.

E-mail: stephenleonj@gmail.com

doi: $10.5937 /$ fme2101078S

(C) Faculty of Mechanical Engineering, Belgrade. All rights reserved of the tool/matrix can be divided as shoulder/matrix and $\mathrm{pin} / \mathrm{matrix}$ contact surfaces. The rotating tool is not only responsible for heat generation but it also stirs the material along the weld line. Although heat generated along pin is comparatively less, it plays a major role in stirring of material around the tool in stir zone[3]. As the tool pin is completely inserted in to the work piece, it contributes more on plastic dissipation of material. It reveals that shoulder design should be optimised on the basis of heat generation whereas tool pin geometry should be designed to improvise the plastic dissipation of material.

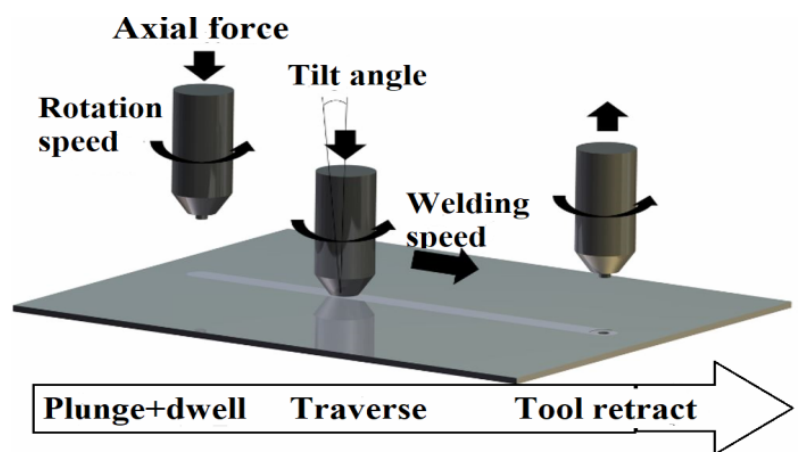

Figure 1. Stages in friction stir welding [4]

Non-circular geometry of the tool pin improvises the flow of material rather than circular shape which results in comparatively better post-weld properties [5]. Many researches designed the tool pin in the view of increasing weld quality. Usage of tool pin with screw threads on its surface reduced weld defects considerably [7]. Colegrove and Shercliff[8] designed much complex pin geometry that contains threads and flutes. The obtained results revealthat threads in the pin improve the material flow and flute increases the contact surface 
so that the heat generation rate is improved. Increase in pin taper angle increases the peak temperature during the process [9] and also it was observed that larger diameter of the pin in the top pushes the material downwards during the process which results uniform properties across the weldment. Apart from this, pin designs like whorl and trivex [10] also increase the material flow. Irrespective of its advantages the complex designs of these pin geometries make it difficult to manufacture.

A few examined tool pins with flat surfaces are easier to manufacture. Increase in the number of flat surfaces in the vertical surface of the tool pin delivers triangular, square, pentagonal and hexagonal crosssection shapes. Various experimental results on the comparison of flat faced pins obtained by different researchers contradict with each other. Fujj et al.[11] achieved defect free weld in triangular shape in softer aluminium alloy AA1050. Bayazid et al.[12] obtained joint with fine grain size with the usage of square pin in the tool. Venkatarao et al.[13] attained better weld strength with the usage of hexagonal tool pin profile in the joining of AA2219 Al-Cu alloy-plates. These facts reveal that along with the pin geometry, the optimization of process parameters with respect to the chosen pin geometry should also be done in order to create an efficient thermal environment which assists the material flow rate along with less property degradation in the heat affected zone.

Every pin shape has a different flow inducing character. Process parameters which are responsible for the increase in process temperature have to be optimized based on the shape of the pin. Increase in process temperature softens the material and develops a convenient environment for the tool pin to increase plastic dissipation. On the other hand, higher process temperature results in microstructure evolution and increases grain size which considerably reduces joint strength. Joining with lower process temperature causes insufficient material flow around the tool which develops weld defects. From these factors it can be understood that the process thermal environment has to be optimised according to the pin geometry as every pin shape has different flow inducing ability.

In this paper, major process influencing parameters are considered along with different pin profiles to attain a maximum possible elevated thermal environment to reduce the stress on the tool pin and to improve material flow in the stir zone without compromising weld quality. Based on the experimental results, correlations are developed to understand the relationship between process temperature, weld quality and number of flat surfaces in pin geometry. Temperature rise in the dwell period is also analysed to obtain an optimum dwell period for the chosen pin geometry.

\section{EXPERIMENTAL ANALYSIS}

\subsection{Development of experimental array}

Design of experiments (DoE) is a statistical technique that has been adopted to perform experimental studies focused in product and process improvement. All the factors in the experiments may vary simultaneously, using DoE. Thus it permits to study the effect of a factor when the conditions of the other factor changes [14] and the interaction among the factors. DoE provides a clear optimization objective strategy (minimization or maximization).

Table 1. Levels of process variables for friction stir welding on AA2024-T3

\begin{tabular}{|c|c|c|c|c|}
\hline \multirow{2}{*}{ Parameter } & \multicolumn{4}{|c|}{ Levels } \\
\cline { 2 - 5 } & 0 & 1 & 2 & 3 \\
\hline $\mathrm{D} / \mathrm{d}$ & 2.5 & 3 & 3.5 & 4 \\
\hline $\mathrm{N}(\mathrm{rpm})$ & 800 & 1000 & 1200 & 1400 \\
\hline $\mathrm{P}_{\mathrm{N}}(\mathrm{kN})$ & 7 & 8 & 9 & 10 \\
\hline $\mathrm{V}_{\mathrm{w}}(\mathrm{mm} / \mathrm{s})$ & 0.75 & 1 & 1.25 & 1.5 \\
\hline
\end{tabular}

The major process influencing and easily controllable process parameters: tool rotation speed, tool dimension, vertical pressure and weld speed were considered in the current analysis. Process parameter ranges for the experiments were selected based on previous studies $[15,16]$ and listed in Table 1 . Design of experiments was made using Minitab software by the input of four levels of the chosen four parameters and an experiement array was developed as shown in Table 2.

Table 2. Experiment array

\begin{tabular}{|c|c|c|c|c|c|}
\hline $\begin{array}{c}\text { Trail } \\
\text { No. }\end{array}$ & $\mathbf{n}$ & $\begin{array}{c}\mathbf{N} \\
(\mathbf{r p m})\end{array}$ & $\begin{array}{c}\mathbf{D} \\
(\mathbf{m m})\end{array}$ & $\begin{array}{c}\mathbf{V}_{\mathbf{w}} \\
(\mathbf{m m} / \mathbf{s})\end{array}$ & $\begin{array}{c}\mathbf{P}_{\mathbf{N}} \\
(\mathbf{k N})\end{array}$ \\
\hline 1. & 3 & 800 & 15 & 0.75 & 7 \\
\hline 2. & 3 & 1000 & 18 & 1 & 8 \\
\hline 3. & 3 & 1200 & 21 & 1.25 & 9 \\
\hline 4. & 3 & 1400 & 25 & 1.5 & 10 \\
\hline 5. & 4 & 800 & 18 & 1.25 & 10 \\
\hline 6. & 4 & 1000 & 15 & 1.5 & 9 \\
\hline 7. & 4 & 1200 & 25 & 0.75 & 8 \\
\hline 8. & 4 & 1400 & 21 & 1 & 7 \\
\hline 9. & 5 & 800 & 21 & 1.5 & 8 \\
\hline 10. & 5 & 1000 & 25 & 1.25 & 7 \\
\hline 11. & 5 & 1200 & 15 & 1 & 10 \\
\hline 12. & 5 & 1400 & 18 & 0.75 & 9 \\
\hline 13. & 6 & 800 & 25 & 1 & 9 \\
\hline 14. & 6 & 1000 & 21 & 0.75 & 10 \\
\hline 15. & 6 & 1200 & 18 & 1.5 & 7 \\
\hline 16. & 6 & 1400 & 15 & 1.25 & 8 \\
\hline
\end{tabular}

\subsection{Tool fabrication}

In order to analyse the effects of tool design, sixteen tools were made with different dimensions and pin profiles. Geometry of the tool pin is varied by choosing the number of sides as a parameter. The tool pin side length was designed in such a way that it occupies same volume during rotation irrespective of its geometrical shape to keep the dynamic swept volume constant. Shoulder diameter changed so as to attain four levels of $\mathrm{D} / \mathrm{d}$ ratio as mentioned in Table 1 .

Selection of tool material is an important factor to be considered. Normally, the material opted for manufacturing the FSW tool should have higher wear resistance, good fatigue life, improved fracture toughness and good chemical stability. Apart from this, the selected material should have superior strength compared with the workpiece material at any elevated 
temperature. It is important to ensure the mechanical and chemical properties of the tool material so that it should not be a source of contamination during the joining process at elevated temperatures. Although the usage of pcBN and tungsten-based alloys as tool materials exhibits superior tool life, they are not cost effective. From the previous experimental results [17], it is observed that principal stress developed on the triangular pin surface is comparatively much higher than other polygonal shapes. Tools with triangular shape pin are made with HSS to improve wear resistance. Apart from this, other tools are made with hardened H13 material. Table 3 reveals the properties of both tool materials. It reveals that thermal properties of bothtool materials are almost the same and the heat lost through the tool made of both materials will not have much deviation.

Table 3. Properties of tool materials

\begin{tabular}{|c|c|c|c|c|c|}
\hline Material & Character & $\begin{array}{c}\mathrm{C}_{\mathrm{p}} \\
\mathrm{J} / \mathrm{kg} \mathrm{K}\end{array}$ & $\begin{array}{c}\mathrm{k} \\
\mathrm{W} / \mathrm{m} \\
\mathrm{K}\end{array}$ & $\begin{array}{c}\rho \\
\mathrm{kg} / \mathrm{m}^{3}\end{array}$ & $\begin{array}{c}\alpha \\
\mathrm{m}^{2} / \mathrm{s}\end{array}$ \\
\hline $\begin{array}{c}\text { High } \\
\text { Speed } \\
\text { steel } \\
\text { (HSS) }\end{array}$ & $\begin{array}{c}\text { High wear } \\
\text { resistance }\end{array}$ & 510 & 28 & 8150 & 0.108 \\
\hline $\begin{array}{c}\text { Hardened } \\
\text { (H13) }\end{array}$ & $\begin{array}{c}\text { Good wear } \\
\text { resistance }\end{array}$ & 470 & 24.3 & 7850 & 0.106 \\
\hline
\end{tabular}

Apart from mechanical and chemical properties, rate of effective heat supply to the workpiece along tool/matrix contact also depends on the thermal properties of tool material. Selection of tool with low thermal conductivity increases the input heat flux towards the workpiece. Increase in the intensity of heat supply to the workpiece enables an increase in welding speed and reduces production time. Thermal diffusivity values of HSS and H13 clearly indicate that irrespective of tool pin shape, the tool material does not have a major influence on the dwell time to achieve the required process peak temperature. Fabricated tools as per the required dimensions are shown in Table 4.

\subsection{Experiment Details}

Welding trails are carried out using Hartford LG 1000 vertical machining centre. AA2024-T3 plates of dimension $300 \mathrm{~mm}$ x $150 \mathrm{~mm}$ x $6 \mathrm{~mm}$ were clamped rigidly on a mild steel backing plate. In order to understand the effects of various parameters on the usage of different pin profiles, sixteen welding trails were done under different input conditions as per the planned experiment array (Table 2). To measure the thermal field in the heat affected zone, a contact type temperature measurement system is adopted. Four Ktype thermocouples (TC) are located approximately at a distance of $\mathrm{R}_{\text {shoulder }}+0.4 \mathrm{~mm}$ as shown in Fig. 2 .

Table 4. Fabricated tools

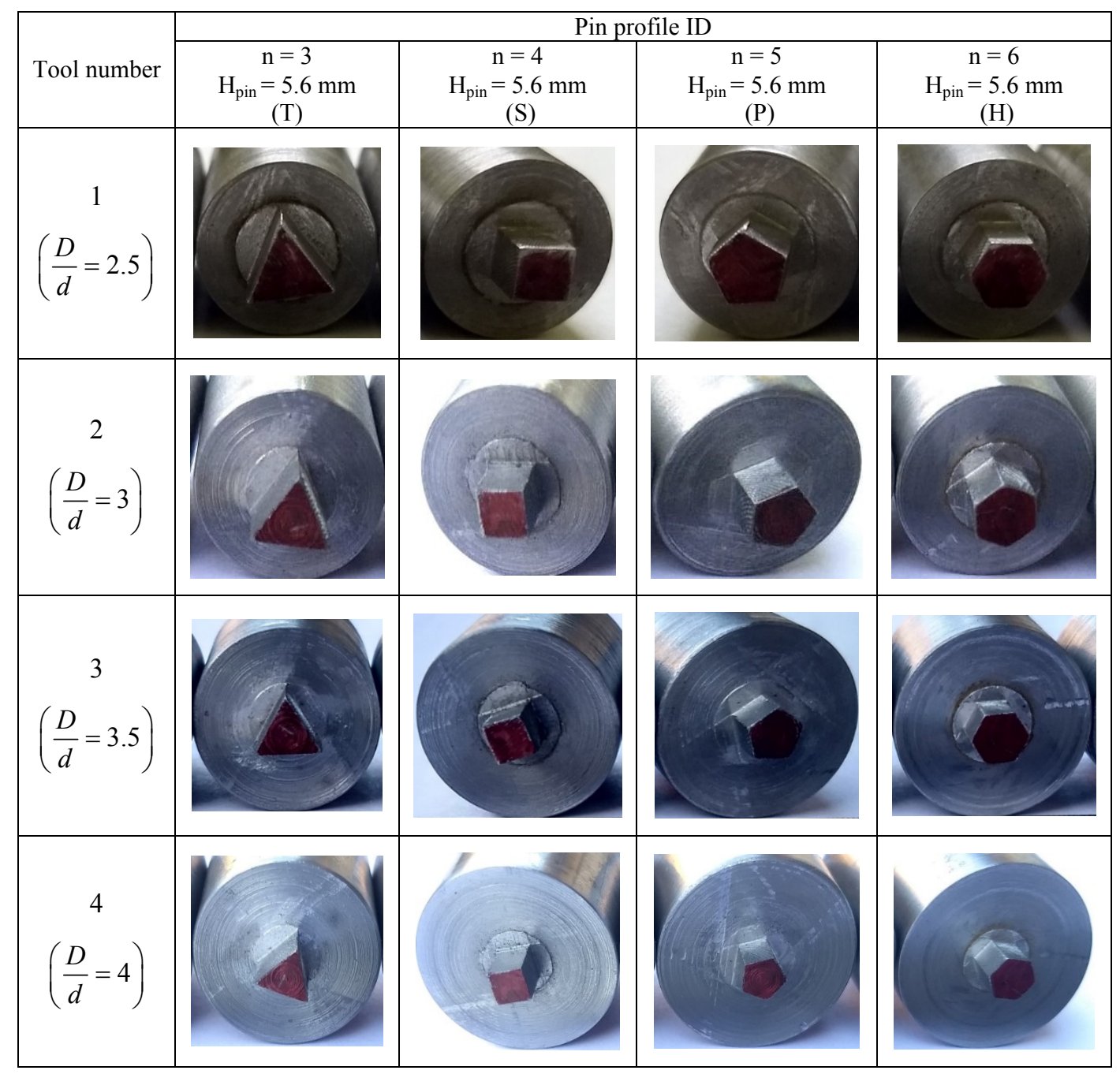




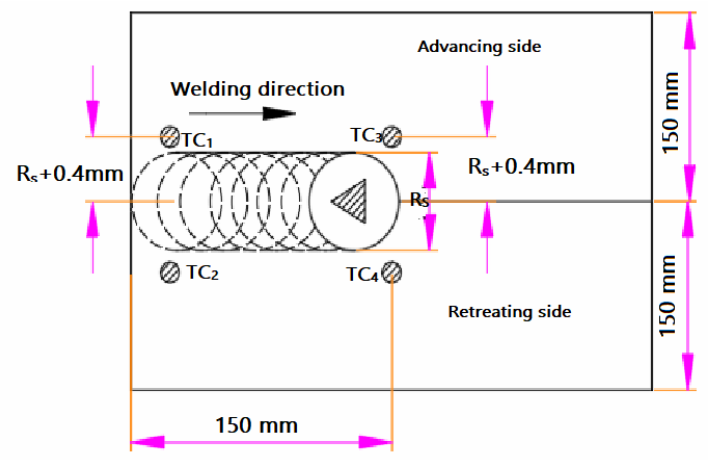

Figure 2. Layout of experiment

From the previous studies $[18,19]$, it is understood that there will be a minor difference in the temperature in the advancing and retreating side during the joining process. In order to consider the temperature difference, two thermocouples are placed in the advancing side and the other two are placed in the retreating side. TC1 and $\mathrm{TC} 2$ are used to measure the temperature rise during the dwell period. This will help to understand the transient thermal field during dwell period and also to understand the time taken to reach quasi steady state for the given input process conditions. TC 3 and TC4 are located in the centre of the base metal in order to measure the peak temperature rise during the welding stage. Average temperature is calculated from the temperature recorded by the advancing and retreating side thermocouple. This average temperature is used for further analysis. Data acquisition system along with vendor supplied software is used to record the temperature sensed by the thermocouples during the process.

\section{RESULTS AND DISCUSSIONS}

\subsection{Thermal analysis}

Plunge period for all the trails starts at $20^{\text {th }}$ second and it continuous up to the $27^{\text {th }}$ second in which the tool shoulder comes into contact with the base metal. There is a steady rise in temperature during plunge period due to the friction developed between the tool pin/matrix contact interfaces. As the heat generated during plunge period is low, its effect on the temperature rise is also very low. Fluctuations in temperature rise are observed in the beginning of the dwell period $\left(27^{\text {th }} \mathrm{sec}\right)$. These fluctuationswere caused by the sudden rise in heat supply due to the friction developed between the tool shoulder/matrix contact surfaces. The temperature during the dwell period increases rapidly till the process reaches its quasi steady state temperature. For all trails the $45^{\text {th }}$ second is set as end of the dwell period to ensure that the process temperature reaches quasi steady state. It can be observed in all the processes that the temperature rise curves become flattened before the $45^{\text {th }}$ second. This indicates that the maximum heat supply varies with respect to the process conditions and maximum achievable process peak temperature depends on the amount of heat supply. It also can be noticed that in every tool pin geometry some trails are carried out with higher heat supply (Trails $3,4,7,8,11,12,14$ \& 16). In these trails the increase in temperature is steady.

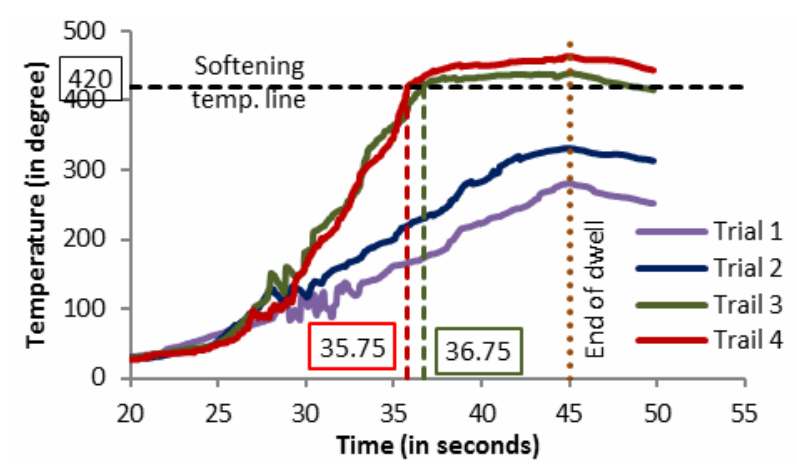

a) Triangular pin

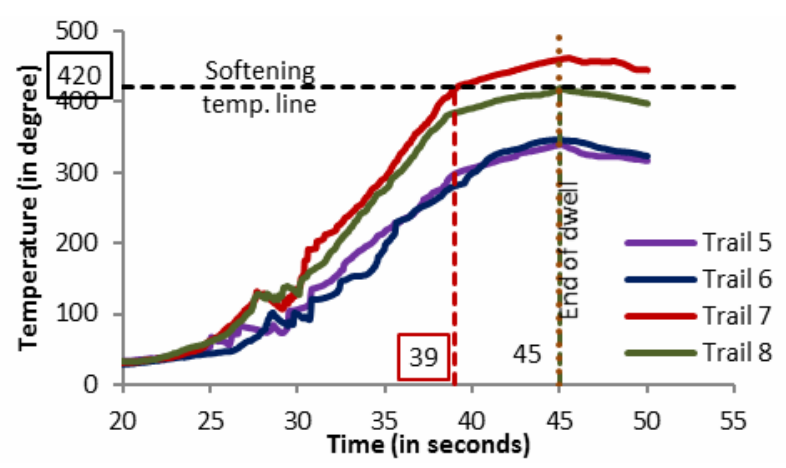

b) Square pin

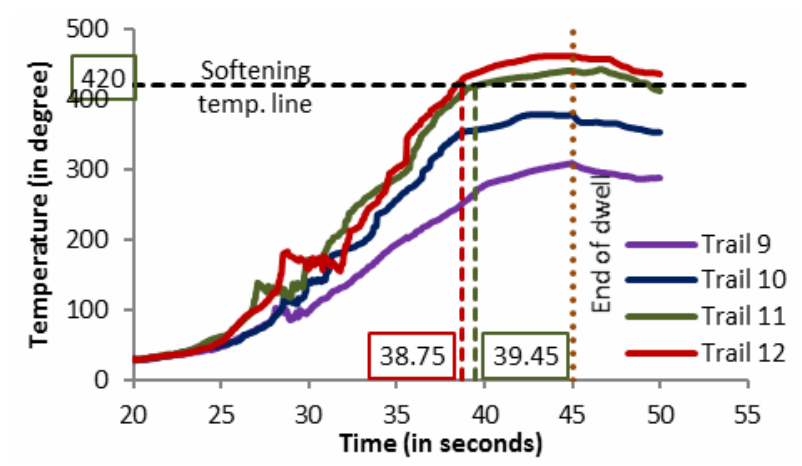

c) Pentagonal pin

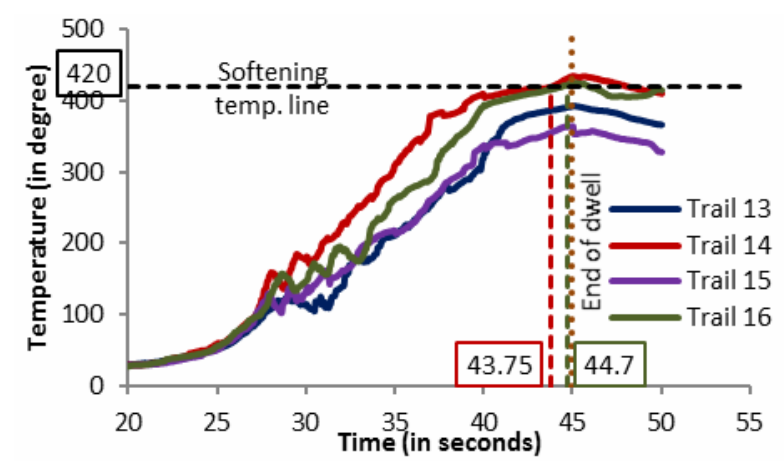

d) Hexagonal pin

Figure 3. Temperature rise during dwell period

When the rise in process peak temperature reaches base material softening temperature $\left(420^{\circ} \mathrm{C}\right)$, the rate of the temperature rise reduces. When the tool/matrix contact surface reaches a temperature closer to the material softening temperature, the base material strength decreases. Due to the reduction in shear strength of the material, its flow velocity around the tool is almost close to the tool velocity. When the relative velocity between the tool and the material under the shoulder decreases, the 
friction in their contact surface also reduces. Due to the reduction in frictional heat, the total heat supply reduces and the rate of temperature rise drops tremendously. In Fig.3, the time taken to reach base material softening indicates that prolonging the dwell time beyond the indicated limit will increase the slip rate and cause a loss in input power. This indicates that the dwell period for these higher heat input trials can be optimised based on the base metal softening temperature in order to increase the efficiency of the process.

\subsection{Hardness test}

Stirring of material under the tool shoulder along the weld line leads to the dynamic recrystalisation of the material in the stir zone (SZ). Microstructure of the base metal in the TMAZ is affected by shear as well as mechanical strain. The combined effect of thermo- mechanical recrystallization leads to a typical recovered microstructure in TMAZ. Normally heat affected zone is not affected by the process and the crystal structure of the material in this zone is almost similar to the base metal. However, in age-hardened alloys, the hardness level tends to decrease in the HAZ.This indicates clearly that the thermal cycle during the welding process has a significant influence, either by over aging, or by decreasing dislocation density or probably by both in fully aged alloys. This uneven grain size in the joined material results in the variation of hardness. The hardness value varies with respect to the distance from the weld centre. Variation in hardness is shown in Fig. 4.

Hardness distribution in the stir zone is a combined effect of the temperature distribution andmaterial flow. The flat-faced pin increases the strain rate rather than the cylindrical pin [20] and it results in uniform grain size in this zone. Considerablefluctuations in hardness values were not observed in the stir zone (Fig. 4). From this it can be understood that the flat-faced pin ensures uniform grain size in the stir zone even though the process is carried out with low heat input. It can also be observed that the decrease in the ratio between the tool shoulder and pin flattens the centre part of the "W" shape curve (Fig.4). This indicates that the percentage contribution of the pin in heat generation increases when the $\mathrm{D} / \mathrm{d}$ ratio decreases which makes the stir zone almost equal to the cylindrical shape. The uniform distribution of heat throughout the stir zone leads to the uniform material flow which results in uniform grain size and hardness value throughout the region.

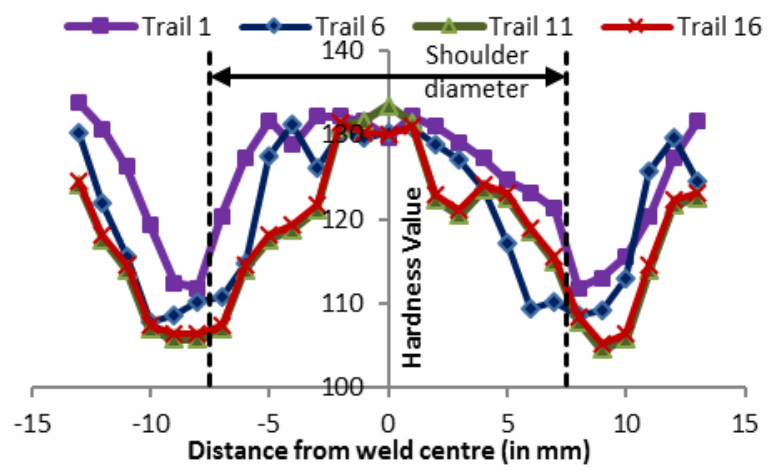

a) Tool shoulder-pin diameter ratio 2.5

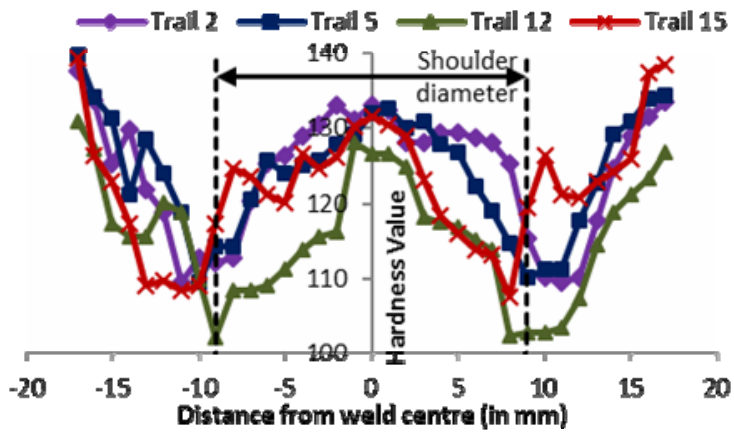

b) Tool shoulder-pin diameter ratio 3

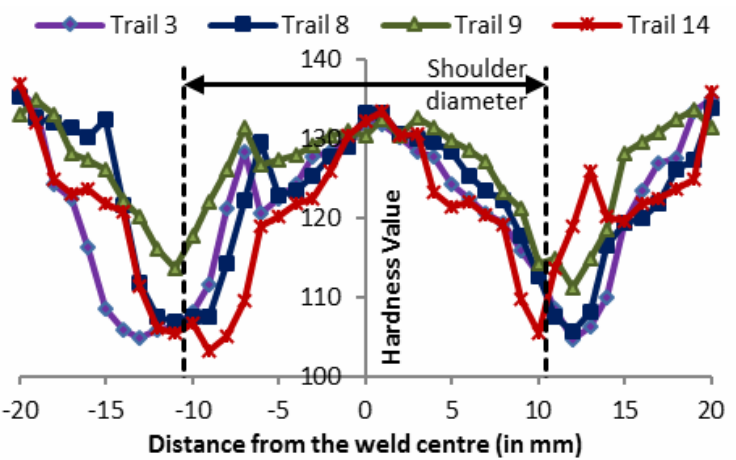

c) Tool shoulder-pin diameter ratio $\mathbf{3 . 5}$

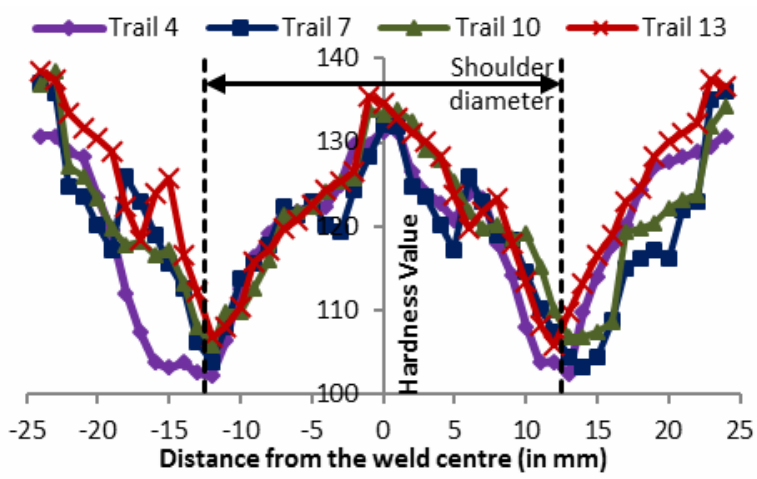

d) Tool shoulder-pin diameter ratio 4

Figure 4. Hardness distribution

Unlike the stir zone, the heat affected zone is not affected by material flow. The hardness distribution in the heat affected zone depends only on the temperature distribution. Temperature dependent grain size decides the hardness value in this zone. When the temperature in this region increases higher than the base material recrytallisation temperature, the grain size in this region increases. This coarsening of grains decreases the density of the strengthening agents and it results in decreased hardness. D/d ratio has a definite effect on the low hardness region. It can be observed from Fig. 4 that the lowest hardness value falls in HAZ when the $\mathrm{D} / \mathrm{d}$ ration is low and it moves to the TMAZ when the $\mathrm{D} / \mathrm{d}$ ratio increases. This is also an indication of higher contribution of tool pin in total heat generation during the process at lower $\mathrm{D} / \mathrm{d}$ ratio which decreases the temperature gradient in TMAZ.

\subsection{Tensile test}

Specimens are collected from every trial (Trail no.1 to 16) for the tensile test. For the current analysis transverse 
tensile properties of friction stir welded joints are analysed. Specimens are cut using wire EDM from the obtained friction stir welded plates. Dimensions of the collected specimens are shown in Fig. $5 \&$ Table 5 and specimens for the tensile test are prepared as per ASTM E8.
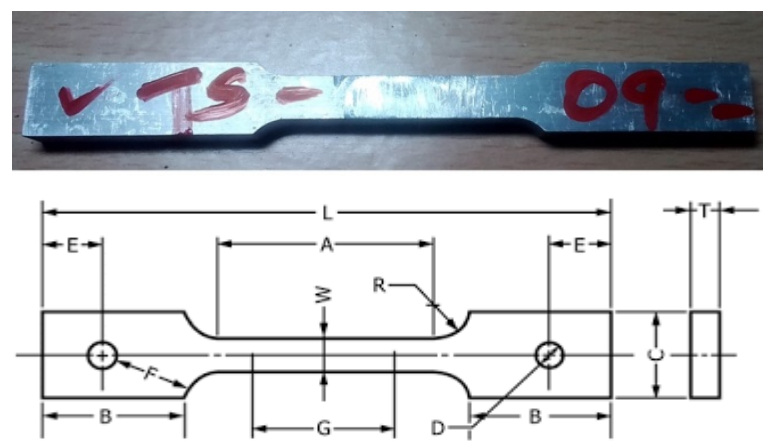

Figure 5. Tensile test specimen sample photograph and layout

Table 5. Dimensions of the tensile test specimen layout

\begin{tabular}{|c|c|}
\hline $\begin{array}{l}\text { Layout notations and } \\
\text { abbreviations }\end{array}$ & Dimension (in mm) \\
\hline G-Gauge length & $50 \pm 0.1$ \\
\hline W-Width & $12.5 \pm 0.2$ \\
\hline T-Thickness & $\begin{array}{c}6 \pm 0.2 \\
\text { (thickness of the plate) }\end{array}$ \\
\hline $\mathrm{R}$-Radius of fillet & 12.5 \\
\hline L-Overall length & 200 \\
\hline $\begin{array}{l}\text { A-Length of reduced parallel } \\
\text { section }\end{array}$ & 57 \\
\hline B-Length of grip section & 50 \\
\hline $\mathrm{C}$-Width of grip section & 20 \\
\hline
\end{tabular}

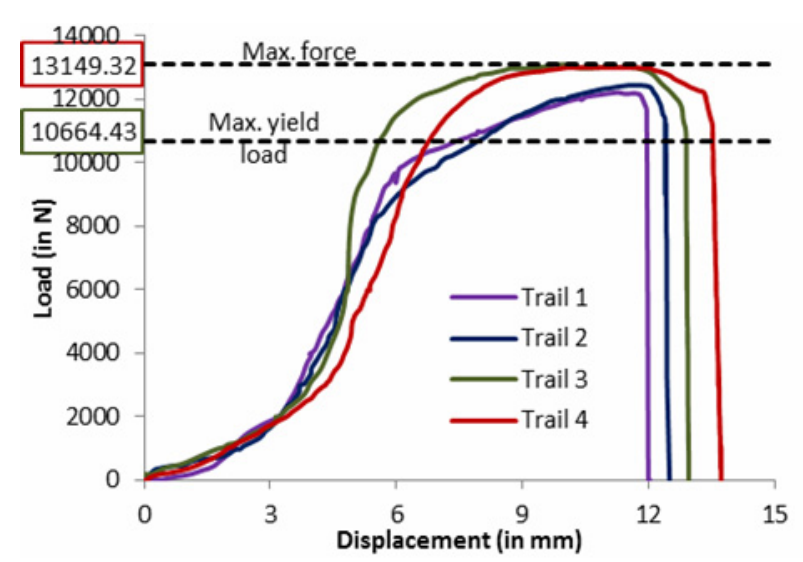

a) Triangular pin

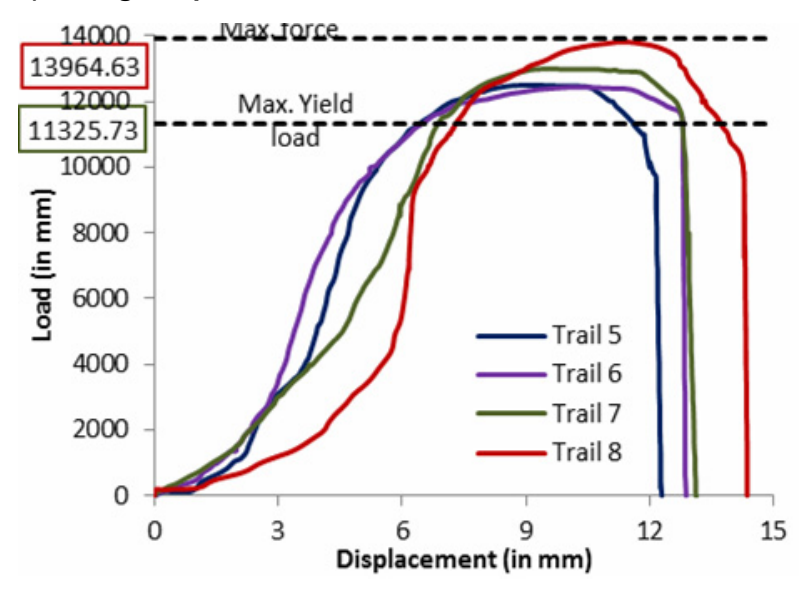

b) Square pin

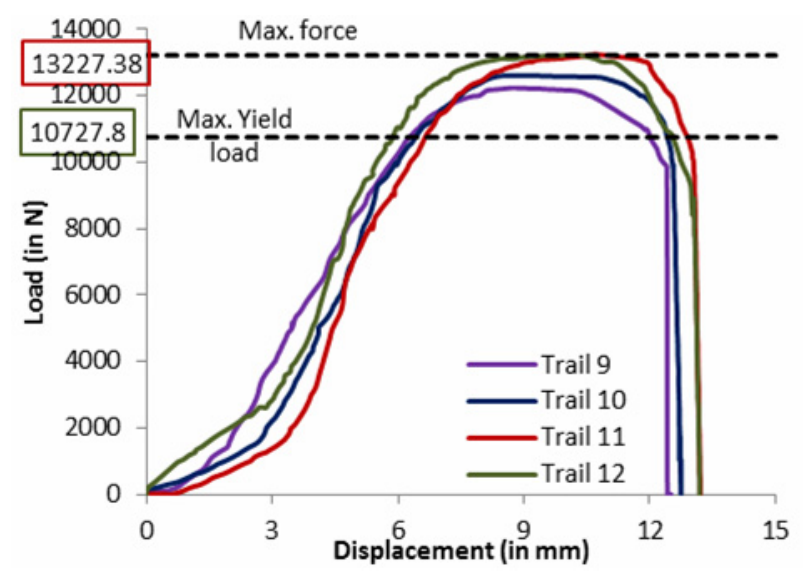

c) Pentagonal pin

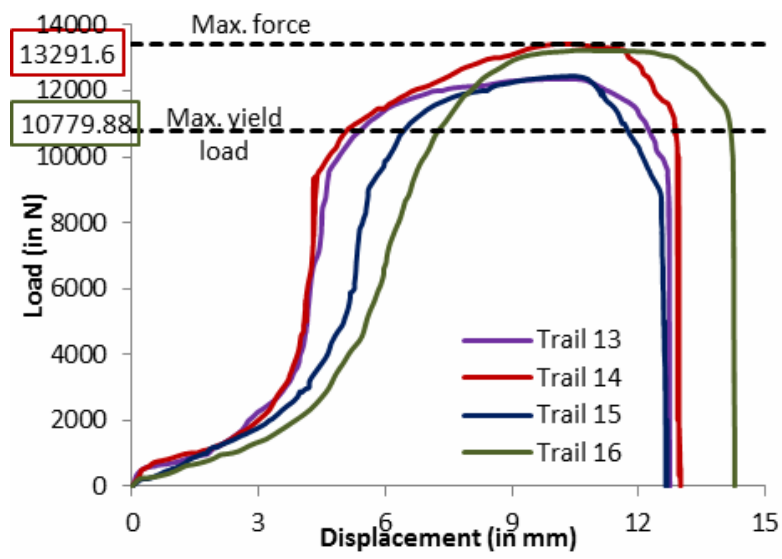

d) Hexagonal pin

Figure 6. Load-Displacement curves

Ultimate strength and yield strength of each specimen is found by using a computerised universal testing machine. The fracture has occurred either in theretreating or advancing side of the weld. Obtained load-displacement curves from the testing of each specimen are shown in Fig. 6.

The friction stir welding flow of material around the tool depends on the major process parameters like axial force and tool rotational speed, apart from that the tool pin profile plays a key role on propelling the material behind the tool in the stir zone during the forward motion of the tool. This indicates that the pin profile plays a crucial role in the development of good joint quality during welding. A part of the input power during friction stir welding process is stored in the microstructure of the base metal and the remaining is converted into heat [21]. Plastic deformation in the stir zone occurs by the frictional torque developing in the top surface of the tool shoulder/matrix interface and by the tool pin face induced extrusion of metal. This indicates that the tool pin profile has its own role on plastic deformation. This can be explained through the volume ratio of the tool pin (actual volume of the tool $\mathrm{pin} / \mathrm{swept}$ volume of the pin during rotation). When the volume ratio decreases for a pin profile the pulsating action developed by the flat surface of the pin increases. The lowest volume ratio is observed in triangular shape (0.41) and the highest is observed in hexagonal shape (0.82). The hexagonal shape almost resembles a straight cylindrical pin profiled tool at high rotational speed. 
When the volume ratio decreases, the material strain rate increases in the stir zone. Because of its lower volumetric ratio, the flat faces of triangular and square pins have comparatively more influence over the material flow than the pentagonal and hexagonal shape. Extensive plastic deformation develops dynamically recrystallised grains [22] which delivers a fine equiaxed grain structure in the stir zone [23]. This attained equiaxed grain structure in the stir zone improves the tensile strength of the welded joint.

From Fig. 6 it can be observed that the maximum ultimate as well as yield stress is observed on the usage of the square pin profile. This indicates that the usage of the square pin tool results in comparatively better equiaxed grain structure than other polygonal shapes. On the other hand, although the volume ratio is too low for the triangular shape, the strength of the joints developed by it does not show major variation compared with the joints developed by a pentagonal and hexagonal tool pin. This is due to the excess strain rate developed by the triangular tool pin which resulted in low strength prolonged grain micro structured joints during mixing [24].

\subsection{Comparative and statistical analysis}

Irrespective of the pin geometry, all shapes occupy a cylindrical volume during rotation. This is called the dynamic volume of the tool pin. When the ratio between static and dynamic volume of the pin reduces, material flow increases. Experimental results shown in Figs. 6 and 7 reveal that the reduction in the number of flat surfaces from 6 to 5 (hexagonal vs pentagonal shape) does not exhibit a major difference in the maximum achievable post weld properties. On the other hand,a huge reduction in maximum achievable ultimate strength is observed when the numbers of flat surfaces in the pin are reduced from 4 to 3 (square vs. triangular shape). This indicates that although the reduction in the volumetric ratio of the pin increases the strain rate and improves the post weld properties, it shows a negative result when the reduction in volumetric ratio is beyond a limit. This is due to the excess strain produced by the triangular pin resulting in elongated grains. Form Fig.7 it is evident that square-shaped pin delivers comparatively better weld quality than other pin geometries.

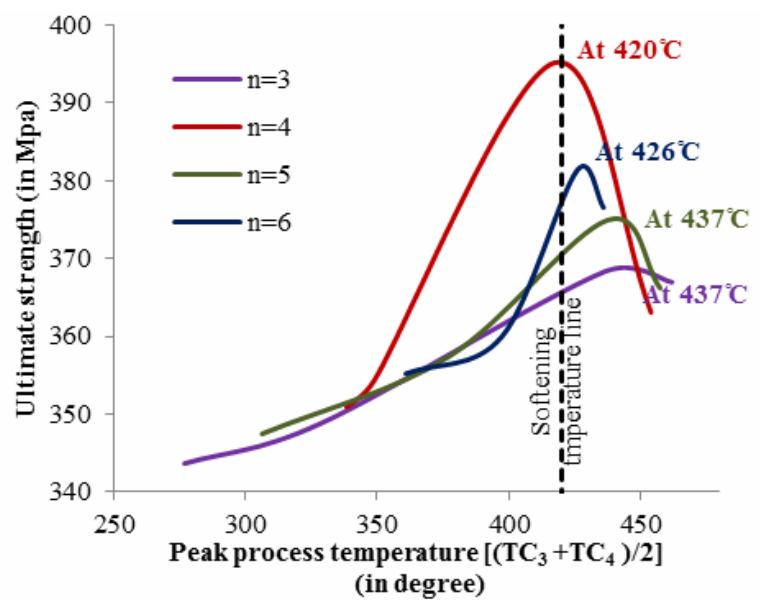

Figure 7. Process peak temperature at welding stage and resulted weld strength
Hexagonal and pentagonal pin profiles require an excess rise in temperature above the material softening temperature to develop a required material flow around the tool. From Fig.7 it can be understood that the optimum thermal condition for these pins is comparatively higher. Although this higher thermal environment facilitates material flow in the stir zone, it eradicates the material properties in the heat affected zone. Material property changes in the heat affected zone reduce the strength of the joint and deliver a comparatively low quality joint rather than the square pin.

Obtained results reveal that there are strong relationships between thermal conditions and post-weld properties during the usage of different pin geometry. In the view of optimising the process parameters in order to attain optimum thermal conditions with respect to the number of flat surfaces used in the tool pin geometry, a regression analysis can be used. The following correlations are obtained using the regression analysis on the basis of obtained experimental results.

Process peak temperature $\mathrm{T}=\mathrm{f}\left(n, \frac{D}{d}, \frac{\omega}{v_{w}}, P_{N}\right)$

$\mathrm{T}=-39.2+8.31(\mathrm{n})+0.94\left(\frac{\omega}{v_{w}}\right)+34.92\left(\frac{D}{d}\right)+20.86 P_{N}$

Ultimate strength $=\mathrm{f}(\mathrm{n}, \mathrm{T})$

Ultimate strength $=289.56+0.172(\mathrm{~T})+1.37(\mathrm{n})$

Table 6.Regression statistics

\begin{tabular}{|c|c|c|}
\hline & Correlation (1) & Correlation (2) \\
\hline Multiple R & 0.840183 & 0.755119 \\
\hline R Square & 0.705908 & 0.570204 \\
\hline $\begin{array}{c}\text { Adjusted R } \\
\text { square }\end{array}$ & 0.598965 & 0.504082 \\
\hline Significance F & 0.005825 & 0.004132 \\
\hline
\end{tabular}

Regression statistics shown in Table 6 explains the reliability of the attained correlations. From both correlations (1 and 2) it is evident that along with other process parameters, the number of flat surfaces in the tool pin is also an important function that could have its own impact on the process temperature as well as postweld properties of the welded joint. Fig.7 explains optimum process temperature for different pin geometry during the welding stage. Based on this, the temperature correlation (1) can be used to predetermine optimum process parameters with respect to the pin geometry.

\section{CONCLUSIONS}

In this work, experimental study was carried out to correlate the relationship between pin geometry, process temperature and weld quality in the view of observing optimum thermal conditions to use flat-faced tool pin in the friction stir welding of AA2024-T3 plates. Based on the obtained results, it can be concluded that number of flat surfaces in the pin geometry has a definite influence over dwell period along with other process parameters. For every tool pin geometry, the dwell period can be fixed based on the time taken to reach the empirical softening temperature of the base material to be joined 
to improve the process efficiency. Lower volumetric ratio of the square pin increases the strain rate so that sufficient material flow is achieved at lower process peak temperature. Comparing all pin geometries, the lowest optimum peak temperature (much closer to the base metal softening temperature) is observed for the square pin. This comparatively lowest thermal process field helps to improve the properties in heat affected zone and delivers a superior weld quality rather than any other polygonal pin profile. Obtained statistical correlations assists in the selection of process parameters with respect to the chosen pin geometry to perform the joining process under an optimum thermal field.

\section{REFERENCES}

[1] J. Stephen Leon, V. Jayakumar, "An investigation of analytical modelling of friction stir welding," Int. J. Mech. Prod. Eng. Res. Dev., vol. 9, no. 1, 2019, doi: 10.24247/ijmperdfeb201918.

[2] H. Li, W. Qin, D. Liu, Q. Li, and Y. Wu, "Design of friction stir welding tools reducing heat flow into spindle," 2017, doi: 10.1007/s00170-017-0985-7.

[3] M. Mehta, G. M. Reddy, A. V Rao, and A. De, "ScienceDirect Numerical modeling of friction stir welding using the tools with polygonal pins," pp. 1-8, 2015, doi: 10.1016/j.dt.2015.05.001.

[4] A. Magalhães, J. De Backer, and G. Bolmsjö, "Thermal dissipation effect on temperaturecontrolled friction stir welding," Soldag. e Insp., vol. 24, pp. 2-10, 2019, doi: 10.1590/01049224/SI24.28.

[5] Stephen Leon J, Bharathiraja G, and Jayakumar V, "Analytical and experimental investigations of optimum thermomechanical conditions to use tools with non-circular pin in friction stir welding," Int. J. Adv. Manuf. Technol., vol. 107, no. 11-12, 2020, doi: 10.1007/s00170-020-05341-7.

[6] R. Nandan, T. Debroy, and H. K. D. H. Bhadeshia, "Recent Advances in Friction Stir Welding Process , Weldment Structure and Properties," vol. 53, pp. 980-1023, 2008.

[7] Y. H. Zhao, S. B. Lin, F. X. Qu, and L. Wu, "Influence of pin geometry on material flow in friction stir welding process," Mater. Sci. Technol., vol. 22, no. 1, pp. 45-50, 2006, doi: 10.1179/174328406X78424.

[8] P. A. Colegrove and H. R. Shercliff, "Twodimensional CFD modelling of flow round profiled FSW tooling," Sci. Technol. Weld. Join., vol. 9, no. 6, pp. 483-492, 2004, doi: $10.1179 / 136217104225021832$.

[9] G. Buffa, J. Hua, R. Shivpuri, and L. Fratini, "Design of the friction stir welding tool using the continuum based FEM model," vol. 419, pp. 381388, 2006, doi: 10.1016/j.msea.2005.09.041.

[10] P. A. Colegrove, H. R. Shercliff, "Development of Trivex friction stir welding tool Part 1 - Two-dimensional flow modelling and experimental validation," Sci. Technol. Weld. Join., vol. 9, no. 4, pp. 345-351, 2004, doi: 10.1179/136217104225021670.
[11]H. Fujii, L. Cui, M. Maeda, and K. Nogi, "Effect of tool shape on mechanical properties and microstructure of friction stir welded aluminum alloys," vol. 419, pp. 25-31, 2006, doi: 10.1016/j.msea.2005.11.045.

[12] S. M. Bayazid, H. Farhangi, and A. Ghahramani, "Effect of Pin Profile on Defects of Friction Stir Welded 7075 Aluminum Alloy," Procedia Mater. Sci., vol. 11, pp. 12-16, 2015, doi: 10.1016/j.mspro.2015.11.013.

[13] C. V. Rao, G. M. Reddy, and K. S. Rao, "Influence of tool pin profile on microstructure and corrosion behaviour of AA2219 Al-Cu alloy Friction Stir Weld Nuggets," Def. Technol., 2015, doi: 10.1016/j.dt.2015.04.004.

[14] J. Antony, T. Chou, and S. Ghosh, "Training for design of experiments," Work Study, vol. 52, no. 7, pp. 341-346, 2003, doi: 10.1108/00438020310502642.

[15]P. Avinash, M. Manikandan, N. Arivazhagan, R. K. Devendranath, and S. Narayanan, "Friction stir welded butt joints of AA2024 T3 and AA7075 T6 aluminum alloys," Procedia Eng., vol. 75, no. September, pp. 98-102, 2014, doi: 10.1016/j.proeng.2013.11.020.

[16] R. C. Brzostek, U. Suhuddin, and J. F. dos Santos, "Fatigue assessment of refill friction stir spot weld in AA 2024-T3 similar joints," Fatigue Fract. Eng. Mater. Struct., vol. 41, no. 5, pp. 1208-1223, 2018, doi: $10.1111 /$ ffe. 12764 .

[17] A. Arora, A. De, and T. Debroy, "Toward optimum friction stir welding tool shoulder diameter," Scr. Mater, vol. 64, no. 1, pp. 9-12, 2011, doi: 10.1016/j.scriptamat.2010.08.052.

[18] J. S. Leon and V. Jayakumar, "Transient heat input model for friction stir welding using non-circular tool pin," FME Trans., vol. 48, no. 1, pp. 137-142, 2020, doi: 10.5937/fmet2001137L.

[19] J. Stephen Leon and V. Jayakumar, "Effect of tool shoulder and pin cone angles in friction stir welding using non-circular tool pin," J. Appl. Comput. Mech., vol. 6, no. 3, 2020, doi: 10.22055/JACM.2019.29340.1585.

[20]K. Elangovan, V. Balasubramanian, and M. Valliappan, "Effect of tool pin profile and tool rotational speed on mechanical properties of friction stir welded AA6061 aluminium alloy," Mater. Manuf. Process., vol. 23, no. 3, pp. 251260, 2008, doi: 10.1080/10426910701860723.

[21] H. B. Schmidt and J. H. Hattel, “Thermal modelling of friction stir welding," vol. 58, pp. 332-337, 2008, doi: 10.1016/j.scriptamat.2007.10.008.

[22] C. A. W. Olea, L. Roldo, J. F. dos Santos, and T. R. Strohaecker, "A sub-structural analysis of friction stir welded joints in an AA6056 Al-alloy in T4 and T6 temper conditions," Mater. Sci. Eng. A, vol. 454-455, pp. 52-62, 2007, doi: 10.1016/j.msea.2006.12.055.

[23] C. D. Marioara, S. J. Andersen, J. Jansen, and H. W. Zandbergen, "The influence of temperature and 
storage time at RT on nucleation of the $\beta^{\prime \prime}$ phase in a 6082 Al-Mg-Si alloy," Acta Mater., vol. 51, no. 3, pp. 789-796, 2003, doi: 10.1016/S1359-6454(02) 00470-6.

[24] N. Gharaibeh, J. A. Al-jarrah, and S. A. Sawalha, "Effect of Pin Profile on Mechanical Properties of 6061 Al Alloy Welded Joints Prepared by Friction Stir Welding," vol. 6, no. 3, pp. 39-42, 2016, doi: 10.5923/j.mechanics.20160603.01.

\section{NOMENCLATURE}

$\mathrm{n} \quad$ Number of flat faces in tool pin

$\mathrm{N} \quad$ Tool rotational speed

D Tool shoulder diameter

d Tool pin diameter

$\mathrm{V}_{\mathrm{w}} \quad$ Welding speed

$\mathrm{P}_{\mathrm{N}} \quad$ Applied force

$\mathrm{H}_{\text {pin }} \quad$ Pin height

$\mathrm{K}$ Thermal conductivity

$\mathrm{C}_{\mathrm{p}} \quad$ Specific heat

\section{Greek symbols}

$\begin{array}{ll}\rho & \text { Density } \\ \alpha & \text { Thermal diffusivity }\end{array}$

ЕКСПЕРИМЕНТАЛНА АНАЛИЗА

ЗАВАРИВАЊА ТРЕЊЕМ КОРИШЪЕЊЕМ

РАВНИХ ИГАЛА КОД АА2024-ТЗ ЛИМОВА

\section{С. Леон Ј, Бхаратираџа Г, Џајакумар В.}

Код заваривања трењем коришћење некружне игле ограничава век трајања алата, иако се добијају релативно бољи заварени спојеви него када се користи кружна игла. Вршна температура процеса утиче на чврстоћу на смицање материјала који тече око игле алата. Одржавање вршне температуре на што нижем нивоу побољшава својства у зони утицаја топлоте али повећава и напон на игли алата. При коришћењу некружне игле долази до неравномерне расподеле напона на површини игле и она брзо отказује. Анализира се оптимална топлотна средина избором одговарајућих параметара процеса и периода задржавања са аспекта геометрије игле. Такође је извршена упоредна анализа утицаја повећања равне површине игле на квалитет шава у смислу стварања одговарајуће топлотне средине која може да побољша животни век алата без угрожавања чврстоће завареног споја. Такође се анализира, на основу искуства са температуром омекшавања материјала, оптимални период задржавања за одабрану геометрију игле. 